\title{
Optimization of growth and electrosynthesis of PolyHydroxyAlcanoates by the thermophilic bacterium Kyrpidia spormannii
}

\author{
Guillaume Pillot ${ }^{a}$, Soniya Sunny ${ }^{a}$, Victoria Comes ${ }^{\text {a }}$, Sven Kerzenmacher ${ }^{\text {a }}$. \\ ${ }^{a}$ Center for Environmental Research and Sustainable Technology (UFT), University of Bremen, 28359 Bremen, Germany
}

\begin{abstract}
The electrosynthesis of valuable compounds by biofilms on electrodes is being intensively studied since few years. However, so far, the actual biofilms growing on cathodes produce mainly small and relatively inexpensive compounds such as acetate or ethanol. Recently, a novel Knallgas bacterium, Kyrpidia spormannii EA-1 has been described to grow on cathodes under thermophilic and microaerophilic conditions, producing significant amounts of PolyHydroxyAlkanoates (PHAs). These PHA are promising sustainable bioplastic polymers with the potential to replace petroleum-derived plastics in a variety of applications. However, the effect of culture conditions and electrode properties on the growth of $K$. spormannii EA-1 biofilms and PHA production is still unclear.

In this study, we report on the optimization of growth and PHA production in liquid culture and on the cathode of a Microbial Electrosynthesis System. Optimization of the preculture allows to obtain high cell density of up to $8.5 \log _{10}$ cells $\cdot \mathrm{ml}^{-1}$ in $48 \mathrm{~h}$, decreasing the time necessary by a factor of 2.5 . With respect to cathodic biofilm formation, this study was focused on the optimization of three main operating parameters, which are the applied cathode potential, buffer $\mathrm{pH}$, and the oxygen concentration in the feed gas. Maximum biofilm formation and PHA production was observed at an applied potential of $-844 \mathrm{mV} v$ s. SCE, $\mathrm{pH} 6.5, \mathrm{O}_{2}$ saturation of 2.5\%. The PHA concentration in the biofilm reached a maximum of $\approx 26.8 \mu \mathrm{g} \cdot \mathrm{cm}^{-2}$ after optimization, but at $2.9 \%$ the coulombic efficiency remains relatively low. We expect that further nutrient limitation will allow the accumulation of more PHA, based on a dense biofilm growth. In conclusion, these findings take microbial electrosynthesis of PHA a step forward towards practical implementation.
\end{abstract}




\section{INTRODUCTION}

Microbial Electrosynthesis Systems (MES) are emerging technologies for the sustainable production of organic compounds and fuels. This technology is based on the ability of some microorganisms, called electrotrophs, to use electrons from the cathode of an electrochemical system as energy source, fixating $\mathrm{CO}_{2}$ into biomass and side products (Rabaey and Rozendal, 2010). Feeding the system with renewable electricity (solar panels, wind turbines etc.), and anthropogenic $\mathrm{CO}_{2}$ makes it a ground breaking concept to reduce the escalation of the current climatic situation (Lovley and Nevin, 2011). Since the first proof-of-concept, a decade ago, research has been carried out on the characterization and optimization of these processes (Prévoteau et al., 2020). Different aspects have been investigated - the biocatalyst, the conditions of culture, and the engineering of the system - in order to increase the productivity and the value of the molecules produced. Until recently, the technology was limited to the production of low added-value acetic acid by homoacetogenic biofilms, with low product concentration $\left(\approx 12 \mathrm{~g} \cdot \mathrm{L}^{-1}\right)$ (Vassilev et al., 2019) and low competitivity compared to fermentation processes. In the last years, the range of products has expanded, associating different metabolisms to elongate the carbon chain up to butyric or caproic acid, with product concentrations up to $3.2 \mathrm{~g} \mathrm{~L}^{-1}$ and $1.5 \mathrm{~g}$ $\mathrm{L}^{-1}$, respectively (Jourdin et al., 2018).

In order to increase the competitiveness of microbial electrosynthesis in comparison to classic fermentation, it is necessary to develop new biocatalysts able to produce high value-added compounds at high rate. Two strategies are been investigated, the engineering of novel metabolic pathways in already described electrotrophs (Kracke et al., 2018), or the isolation of new electrotrophs from the environment with interesting metabolic capabilities. The discovery of novel metabolisms requires to focus on extreme or unusual environments where microorganisms evolved in response of stresses by developing new metabolisms (Coker, 2016). Extreme conditions, such as high temperature, salinity, pressure or extreme $\mathrm{pH}$ are also profitable for MES operation (Jourdin and Burdyny, 2021). Indeed, the increase of optimal temperature is known to increase the metabolic rate of microorganisms, avoid contaminations and increase electrolyte conductivity. Higher salinity increases the conductivity of the electrolyte and general performances. The acidic or alkaline $\mathrm{pH}$ tolerances allow higher $\mathrm{pH}$ imbalance at the electrodes. Higher pressure increases $\mathrm{CO}_{2}$ solubility and availability. So far, only few extremophilic electrotrophs have been identified. Two acetogenic thermophiles, Moorella thermoacetica and Moorella thermoautotrophica were tested at temperatures up to $70^{\circ} \mathrm{C}$ (Faraghiparapari and Zengler, 2017). Pillot et al. (2020, 2021) have shown the enrichment of electrotrophic communities from deep-sea hydrothermal vents, dominated by Archaeoglobales, producing pyruvate, glycerol, and acetate at $80^{\circ} \mathrm{C}$ in seawater. These communities were dominated by Archaeoglobales, known to use the Wood-Ljungdahl pathway to fix $\mathrm{CO}_{2}$. Alqahtani et al. (2019) have shown the enrichment of halophilic homoacetogens in MES, dominated by Marinobacter sp., from Red Sea Brine Pool. Unfortunately, the metabolic ability of these electrotrophs doesn't seems yet to increases the range of products or increases yields in a significant way. Recently, Reiner et al. (2020) have reported on a thermoacidophilic electrotrophic community enriched from geothermal hot springs on the Azores. From this community, they succeeded to isolate a novel microaerophilic Knallgas bacterium, Kyrpidia spormannii EA-1, able to produce PolyHydroxyAlcanoates (PHA) from $\mathrm{CO}_{2}$ on a cathode. Since this isolation, two additional strains were isolated from Pantelleria Island in Italy (Hogendoorn et al., 2020)

PHA are of great biotechnological interest as precursor for bioplastic production. They are biobased and biodegradable polyesters, used as energy storage in intracellular granules or involved in maintenance of anoxic photosynthesis and sulfur cycle in microbial mats (Obruca et al., 2020). More than 150 different monomers can be combined leading to extremely different properties. Different species have been described to produce PHA, such as Alcaligenes latus, Cupriavidus necator, and Pseudomonas putida. PHA accumulation is usually produced by fermentation of feedstock and promoted when an essential nutrient for growth is present in limited amount in the cultivation medium, whereas an organic carbon source is in excess (Kourmentza et al., 2017). The actual production cost of PHA is still 3-4 times higher compared to conventional polymers such as polypropylene or polyethylene (Panuschka et al., 2019). Electrosynthesis of PHA could drastically reduce the production cost, by replacing costly organic 
carbon source by inexpensive $\mathrm{CO}_{2}$ and increasing the purity of the end product.

In this context, Kyrpidia strains are excellent candidates as biocatalyst for PHA electrosynthesis. However, prior to assess the competitivity of the process a significant effort of optimization is necessary. These microaerophilic organisms are highly sensitive to $\mathrm{O}_{2}$ concentration and experimental conditions can highly influence their growth rate and productivity. Previous cultivation methods of this strain required more than 7 days of liquid culture to obtain significant growth, slowing down its characterization and optimization in MES. In this study, we aimed to optimize the growth of $K$. spormannii EA-1 in liquid culture and on cathode for the production of PHA. For the optimization in liquid media, a protocol for the culture in serum bottle of another Knallgas bacteria, Aquifex aeolicus (Uzarraga et al., 2011), was adapted and optimized by experimental design on different factors: the quantity of gaseous substrate represented by the ratio gas/liquid, the redox state of the medium (anaerobic/aerobic preparation), the mixing during incubation and the electron donor nature. For the electrotrophic growth on cathode, the electrode potential, the oxygen concentration and the $\mathrm{pH}$ of the media were tested independently and the associated current consumption, biofilm produced, and accumulation of PHA were quantified.

\section{MATERIAL AND METHODS}

\section{Bacterial strain and culture media}

K. spormannii EA-1 cultures were obtained from cryostock from the Applied Biology group of Johannes Gescher at the Karlsruhe Institute of Technology (Germany) and sub-cultured at $4 \%$ in $100 \mathrm{ml}$ serum bottles closed with a rubber stopper and filled with ES-medium before inoculation of the experimental design media or Microbial Electrochemical Systems (MES). The ES medium was prepared anaerobically (medium with low redox potential, coded $\mathrm{N}_{2}$ ) or not (medium with high redox potential, coded $\mathrm{O}_{2}$ ), with the following content (all procured from Carl Roth, Germany) per litre: $0.53 \mathrm{~g}$ $\mathrm{NH}_{4} \mathrm{Cl}, 0.15 \mathrm{~g}$ of $\mathrm{NaCl}, 0.04 \mathrm{~g}$ of $\mathrm{KH}_{2} \mathrm{PO}_{4}, 0.2 \mathrm{~g}$ of yeast extract, $1 \mathrm{ml}$ of $0.1 \mathrm{M} \mathrm{CaCl}_{2}, 0.12 \mathrm{ml}$ of $1 \mathrm{M}$ $\mathrm{MgSO}_{4}$, and $1 \mathrm{ml}$ of Wolfe's Mineral Elixir (Wolin et al., 1963) and was adjusted at $\mathrm{pH}$ 5.5. In the anaerobic preparation, the media was supplemented with $0.5 \mathrm{~g} / \mathrm{L}$ of Cysteine- $\mathrm{HCl}$ and $1 \mathrm{mg} / \mathrm{L}$ of Resazurin, boiled for $15 \mathrm{~min}$ and cooled down under $\mathrm{N}_{2}$ degassing. The volume in the serum bottles was adjusted at $50 \mathrm{ml}$ media $+60 \mathrm{ml}$ gas head space or $25 \mathrm{ml}$ media $+85 \mathrm{ml}$ gas head space and autoclaved. After inoculation, the headspace of the serum bottle was replaced by air at atmospheric pressure, and as electron donor either $20 \mathrm{mM}$ of Acetate a mixture of $\mathrm{H}_{2}: \mathrm{CO}_{2}(80: 20)$ at an overpressure of $1.5 \mathrm{bar}$ were added for the liquid cultures, depending on the condition tested. The media were incubated at $60^{\circ} \mathrm{C}$ and either shaken at $150 \mathrm{rpm}$ in an incubator (Incubator 3032, GFL, Germany) or kept static (Incudrive H, Schuett Biotec, Germany).

\section{Experimental design for the optimization of liquid culture growth}

The software Design Expert v13.0 was used to perform a two-level factorial design with four factors: shaking of the media, substrate used, redox state of the medium, and ratio gas/liquid. The conditions for the 16 runs are presented Table 1 . Three responses were measured each day for 3 days to evaluate the growth of $K$. spormannii: optical density (OD) at $600 \mathrm{~nm}$, qPCR quantification, and PHA quantification (see below for details).

Table 1: Experimental Design for the optimization of the growth of Kyrpidia spormannii in liquid media on the four factors with A: Shaking, B: Substrate, C: Media preparation, D: Ratio liquid/gas in the bottle.

\begin{tabular}{|c|c|c|c|c|}
\hline & $\mathrm{A}$ & $\mathrm{B}$ & $\mathrm{C}$ & $\mathrm{D}$ \\
\hline Shaking & Substrate & $\begin{array}{c}\text { Media } \\
\text { prepara } \\
\text { tion }\end{array}$ & $\begin{array}{c}\text { Ratio } \\
\text { liquid/gas }\end{array}$ \\
\hline Run 1 & Yes & $\mathrm{H}_{2}: \mathrm{CO}_{2}$ & $\mathrm{~N}_{2}$ & $50 / 60$ \\
\hline Run 2 & Yes & $\mathrm{H}_{2}: \mathrm{CO}_{2}$ & $\mathrm{O}_{2}$ & $25 / 85$ \\
\hline Run 3 & Yes & Acetate & $\mathrm{O}_{2}$ & $50 / 60$ \\
\hline Run 4 & No & $\mathrm{H}_{2}: \mathrm{CO}_{2}$ & $\mathrm{O}_{2}$ & $50 / 60$ \\
\hline Run 5 & No & Acetate & $\mathrm{O}_{2}$ & $50 / 60$ \\
\hline Run 6 & No & Acetate & $\mathrm{N}_{2}$ & $50 / 60$ \\
\hline Run 7 & No & Acetate & $\mathrm{N}_{2}$ & $25 / 85$ \\
\hline Run 8 & No & $\mathrm{H}_{2}: \mathrm{CO}_{2}$ & $\mathrm{~N}_{2}$ & $25 / 85$ \\
\hline Run 9 & No & Acetate & $\mathrm{O}_{2}$ & $25 / 85$ \\
\hline Run 10 & Yes & $\mathrm{H}_{2}: \mathrm{CO}_{2}$ & $\mathrm{O}_{2}$ & $50 / 60$ \\
\hline Run 11 & No & $\mathrm{H}_{2}: \mathrm{CO}_{2}$ & $\mathrm{~N}_{2}$ & $50 / 60$ \\
\hline Run 12 & Yes & Acetate & $\mathrm{N}_{2}$ & $50 / 60$ \\
\hline Run 13 & No & $\mathrm{H}_{2}: \mathrm{CO}_{2}$ & $\mathrm{O}_{2}$ & $25 / 85$ \\
\hline Run 14 & Yes & Acetate & $\mathrm{O}_{2}$ & $25 / 85$ \\
\hline Run 15 & Yes & Acetate & $\mathrm{N}_{2}$ & $25 / 85$ \\
\hline Run 16 & Yes & $\mathrm{H}_{2}: \mathrm{CO}_{2}$ & $\mathrm{~N}_{2}$ & $25 / 85$ \\
\hline
\end{tabular}


Each run was performed as triplicate and the average of each response was used during the ANOVA test. The selection of the factors was performed on the full factor interactions with the autoselection using the AICc criteria and respecting the hierarchy. The $\mathrm{OD}_{600 \mathrm{~nm}}$ measurement was performed on a spectrophotometer and the $\mathrm{OD}_{600 \mathrm{~nm}}$ at $24 \mathrm{~h}, 48 \mathrm{~h}$ and $72 \mathrm{~h}$ was normalized to the OD600nm after inoculation.

\section{Microbial Electrochemical System for electrotrophic growth experiments}

Optimization of biofilm growth was performed in a 6-electrode battery glass reactor, previously described (Erben et al., 2021), for the optimization of cathode potential, and in $\mathrm{H}$-cells to allow the separation of conditions for optimization with respect to $\mathrm{O}_{2}$ concentration and $\mathrm{pH}$. The cathode was a $2.25 \mathrm{~cm}^{2}$ exposed surface of graphite plate (Müller \& Rössner $\mathrm{GmbH} \&$ Co KG, Germany), the anode was a Ir-Ta mesh (Umicore, Belgium; $\sim 15 \times 15 \mathrm{~mm}$ ), and the reference electrode was a Saturated Calomel Electrode (SCE, offset of $-215 \mathrm{mV}$ vs. SHE at $60^{\circ} \mathrm{C}$, Sensortechnik Meinsberg, Germany). The cathodes were rinsed with DI water and cleaned in an ultrasonic bath for 5 mins prior to be connected to a potentiostat (IPS Elektroniklabor, PGU-MOD-500mA, Münster, Germany) by titanium wires. The media was filled in the systems, $0.1 \mathrm{M}$ of PBS buffer with required $\mathrm{pH}$ was added, then the systems were closed and autoclaved. The systems were agitated with a magnetic stirrer at $150 \mathrm{rpm}$. The gas mixture $\left(\mathrm{N}_{2}: \mathrm{CO}_{2}\right.$ at $\left.77.5: 20\right)$ was purged continuously in the system using flow meters (Analyt-MTC, Germany) and the $\mathrm{O}_{2}$ concentration was adjusted and monitored by an oxy-meter (Oxy-4 Mini, PreSens, Germany). The MES were placed in an incubator (Schuett Biotec.de, Incudrive H, Germany) at a constant temperature of $60^{\circ} \mathrm{C}$. When the conditions were stabilized after $4 \mathrm{~h}$, the system was inoculated at $2 \%(\mathrm{v} / \mathrm{v})$ with a liquid culture obtained after $48 \mathrm{~h}$ with the optimal conditions identified in the previous part.

\section{Fluorescence microscopy}

Fluorescence microscopy analysis was used for visual confirmation and quantification of biofilm formation on the cathode after the electrochemical experiments. Upon completion of the experiment, bacterial cells were fixed to the electrode using $4 \%$ glutaraldehyde in PBS $0.1 \mathrm{M}$ for $30 \mathrm{mins}$ and later washed in DI water. The fixed electrodes were stained with $2 \mu \mathrm{g} \cdot \mathrm{ml}^{-1}$ DAPI (4',6-diamidino-2-phenylindole) and Nile Red (Carl Roth, Germany) and incubated in the dark for 30 mins. The stained biofilm on the electrode material were visualised using a Zeiss Microscope Axioscope 5/7 (Solid-State Light source Colibri 3 (Type RGB-UV), Microscopy Camera Axiocam 702 mono) (Zeiss, Germany) at 250x magnification (Objective ApoChrom 25x) under oil immersion and subsequently the $\mathrm{z}$-stacks were automatically captured with the motorized stage on the Zen software (Zeiss, Germany, version 3.0). The fluorescence microscopy image data were further processed to obtain the $\mathrm{Z}$ projection of the image stacks and the cell counting was done using Cellc12 software (Selinummi et al., 2005)

\section{Biofilm quantification by means of qPCR}

After the experiment, the cathodes containing the biofilm were taken from the bioelectrochemical reactor and sonicated for $10 \mathrm{~min}$ in $10 \mathrm{ml}$ DI water in order to detach the biofilm from the electrode surface. Furthermore, the 16S rRNA gene was partially amplified by the qPCR method in an Eco 48 Real Time PCR System (PCRmax, United Kingdom), using the qPCRBio SyGreen 2x-Mix (Nippon Genetics Europe, Germany), and the primers Alyc630F (5'GAGAGGCAAGGGGAATTCC-3') and 806R (5'GGACTACHVGGGTWTCTAAT-3'). A standard curve was prepared through cloning method using pGEM(R)-T Easy Vector System II (Promega) and JM109 Competent Cells (Promega). The plasmid was extracted with PureYield ${ }^{\text {TM }}$ Plasmid Miniprep System (Promega) and quantified on a Quantus ${ }^{\mathrm{TM}}$ Fluorometer using the QuantiFluor(R) dsDNA System (Promega). The quantification of copies of $16 \mathrm{~S}$ rDNA was divided by the number of copies naturally present per cell $(5$ copies $\cdot$ cell $^{-1}$ according to $\mathrm{rnDB}$ database), to obtain the number of cells $\cdot \mathrm{ml}^{-1}$.

\section{PHA quantification}

Sonicated biofilm samples (see above) were prepared by alkaline hydrolysis according to Watanabe et al., (2012) with $1 \mathrm{ml}$ of sample in $500 \mu \mathrm{l}$ of $3 \mathrm{~N} \mathrm{NaOH}$, heated at $100^{\circ} \mathrm{C}$ for $3 \mathrm{~h}$, then neutralized with $500 \mu \mathrm{l}$ of $3 \mathrm{M} \mathrm{HCl}$. A standard solution of poly(3hydroxy-butyrate) (average Mn 500,000, Sigma Aldrich) was prepared using the same method. A HPLC system (Alliance, Waters) equipped with a UV/Vis detector (2489 Detector, Waters) monitored at $210 \mathrm{~nm}$ was used for the analysis of crotonic acid produced by the hydrolysis step. The column was a 
Waters Atlantis C18, (Waters, United Kingdom, $250 \mathrm{~mm} \times 4.5 \mathrm{~mm}$, particle size $5 \mu \mathrm{m}$ ). The column temperature was set to $30^{\circ} \mathrm{C}$. The mobile phase was $0.014 \mathrm{~N} \mathrm{H}_{2} \mathrm{SO}_{4}$ at a flow rate of $0.7 \mathrm{~mL} \mathrm{~min}^{-1}$. Before injection, samples were filtered through $0.45 \mu \mathrm{m}$ pore size membrane filter (Minisart High Flow, Sartorius, Germany). A volume of $10 \mu \mathrm{L}$ was injected into the instrument for analysis.

\section{Coulombic Efficiency}

The Coulombic efficiency (CE) of the PHA production was calculated using the formula:

$$
\begin{aligned}
C E(\%)= & \frac{C p}{C t} \times 100 \\
& =\frac{\mathrm{F} \times n_{e} \times \Delta[\mathrm{P}] \times V_{\text {catholyte }}}{\int_{t 0}^{t} i(t) . d t}
\end{aligned}
$$

$C_{T}$ : total coulombs consumed

$C_{P}$ : coulombs found in the product

ne: Number of mol of electrons per mol of product

$F$ : Faradays constant $(96.485 \mathrm{C} / \mathrm{mol})$

$\Delta[\mathrm{P}]:$ Variation of product concentration from $\mathrm{t}_{0}$ to

$V_{\text {catholyte }}$ : Volume of reaction

The total amount of current consumed by the system was calculated by integrating the area under current (A) vs. time (s). The quantity of electrons contained in the final product was calculated using 66 $\mathrm{e}^{-}$equivalent per mole of PHB (Islam Mozumder et al., 2015), obtained from the stoichiometry of PHA production in autotrophic condition, using 33 moles of $\mathrm{H}_{2}$ for the production of 1 monomer of PHA.

\section{RESULTS AND DISCUSSION}

\section{Optimization of growth of Kypridia spormannii in liquid media}

The effect of four factors on the growth of $K$. spormannii EA-1 in liquid media was tested: The shaking of the bottle, the substrate used, the media preparation (aerobic, anaerobic, addition of reducing agent) and the gas/liquid volume ratio. These four factors directly or indirectly affect the oxygen concentration, which can be limiting or toxic $\left(\mathrm{O}_{2}\right.$ quantity and transfer), the growth kinetics $\left(\mathrm{H}_{2}\right.$ or Acetate), and the redox state of the medium (resazurin, $\mathrm{H}_{2}, \mathrm{O}_{2}$ ). The growth was measured by three techniques: $\mathrm{OD}_{600 \mathrm{~nm}}$ determination, qPCR quantification, and PHA production. The respective graphs are presented in Supplementary data S1. The ANOVA analysis of the experimental design on the 3 responses are presented in Table 2.

As shown in Fig. S1, in most experimental runs the OD $600 \mathrm{~nm}$ increased, a maximum of $0.993 \pm 0.09$ was observed in case of run 7. Only the Run 14 and 6 didn't show any growth during the 4 days of experiment. The runs 7 and 15 showed a delay in the growth with a plateau only at 3 days, while all others plateaued after 2 days. The coefficient of determination $\mathrm{R}^{2}$ obtained by the ANOVA model for $24 \mathrm{~h}, 48 \mathrm{~h}$, and $72 \mathrm{~h}$ were all relatively high, with a Predicted $\mathrm{R}^{2}$ in reasonable agreement with the Adjusted $\mathrm{R}^{\mathbf{2}}$ (difference is less than 0.2 ), and the Adequate Precision is greater than 4, indicating that the ANOVA model is significantly representative. It allows to identify that the shaking of the media and the use of $\mathrm{H}_{2}: \mathrm{CO}_{2}$ instead of acetate had a significant positive effect on the $\mathrm{OD}_{600 \mathrm{~nm}}$ after $24 \mathrm{~h}$, to obtain a maximum OD $600 \mathrm{~nm}$ of 0.312 . The media preparation method had only an effect in combination with the substrate used. After $48 \mathrm{~h}$, the use of $\mathrm{H}_{2}: \mathrm{CO}_{2}$, with anaerobic media preparation and a ratio $25 \mathrm{ml}$ media/85 $\mathrm{ml}$ gas had a positive effect on the OD600nm compared to their respective alternatives, yielding a maximum of 0.754 . The shaking presented a significant effect only in combination with substrate and ratio factors.

Finally, when assessed after $72 \mathrm{~h}$, only the media preparation didn't have a significant effect on growth. A maximum OD600nm of 0.983 was achieved with static culturing with acetate and a ratio of $25 \mathrm{ml}$ liquid and $80 \mathrm{ml}$ gas. These results indicate that a faster growth is obtained during the first day with $\mathrm{H}_{2}$ as substrate, to then reach a limitation with $\mathrm{O}_{2}$ concentration after $48 \mathrm{~h}$ and subsequently reach a plateau with most of conditions after $72 \mathrm{~h}$. The $\mathrm{OD}_{600 \mathrm{~nm}}$ measurement is a quick technique to assess the growth of most microorganisms but can be falsified by the production of intracellular granules or EPS, increasing artificially the absorbance with a constant number of cells. To overcome this potential issue, a second quantitative method was performed, based on the quantification of the $16 \mathrm{~S}$ rDNA by qPCR.

The qPCR measurement shows a cell concentration (corrected with the number of copies of 16S rDNA per cells) of $5.32 \pm 0.22 \log _{10}$ cells $\cdot \mathrm{ml}^{-1}$ after inoculation, increasing up to a maximum of $8.43 \pm 0.56$ $\log _{10}$ cells $\cdot \mathrm{ml}^{-1}$ in the run 9 after $72 \mathrm{~h}$. Only Run 6 didn't show any growth, with slight growth on Run 14, 
that was not visible on the OD600nm, potentially due to a higher detection threshold with $\mathrm{OD}_{600 \mathrm{~nm}}$ measurement or heterogeneity in the samples. Most of the runs with acetate $(3,5,6,12,14$ and 15) showed lower growth than the runs with $\mathrm{H}_{2}: \mathrm{CO}_{2}$. The fit statistics of the ANOVA indicated that all 3 models were significant (Table 2). The model shows higher cell density with $\mathrm{H}_{2}: \mathrm{CO}_{2}$ and a gas/liquid ratio of $50 / 60$ after the first day, and with acetate and a ratio of $25 / 85$ at $48 \mathrm{~h}$ and $72 \mathrm{~h}$. The maximum cell concentrations in the identified optimal conditions are 7.23, 7.80 and $8.40 \log _{10}$ cells $\cdot \mathrm{ml}^{-1}$ at $24 \mathrm{~h}, 48 \mathrm{~h}$ and $72 \mathrm{~h}$ respectively. The difference between the qPCR and $\mathrm{OD}_{600 \mathrm{~nm}}$ results, with poor correlations (maximum of $\mathrm{R}^{2}=0.766$ at $48 \mathrm{~h}$ ) presented Fig S2-A, could be explained by the production of PHA over the growth, only detected with OD $600 \mathrm{~nm}_{\text {measurements. }}$

The PHA quantification shows an increase from 3.0 $\pm 0.3 \mathrm{mg} \cdot \mathrm{L}^{-1}$ to up to $29.3 \pm 1.2 \mathrm{mg} \cdot \mathrm{L}^{-1}$ on run 7 after $72 \mathrm{~h}$. The coefficients of determination at $24 \mathrm{~h}$ and $48 \mathrm{~h}$ are close to 1 but decrease to 0.83 after $72 \mathrm{~h}$. The statistics of the ANOVA models show a good fit to our data. During the first days, the shaking, the use of $\mathrm{H}_{2}: \mathrm{CO}_{2}$, the anaerobic media preparation in combination with a volume ratio of $25 / 85$ are significant factors on the PHA production, allowing to reach maximums of $14.9 \mathrm{mg} \cdot \mathrm{L}^{-1}$ at $24 \mathrm{~h}$ and 18.8 $\mathrm{mg} \cdot \mathrm{L}^{-1}$ at $48 \mathrm{~h}$. After $72 \mathrm{~h}$, the use of acetate in a static culture became the best conditions to reach a maximum PHA production of $26.3 \mathrm{mg} \cdot \mathrm{L}^{-1}$. As previously observed on OD $600 \mathrm{~nm}$, the use of $\mathrm{H}_{2}: \mathrm{CO}_{2}$ as substrate and a good mixing allow a faster growth and PHA production, but additionally, the presence of a reduced media seems to induce the production of PHA. The higher PHA production in the absence of shaking after $72 \mathrm{~h}$ could also be explained by the lower $\mathrm{O}_{2}$ dissolution into the liquid. Indeed, in Cupriavidus necator, it was reported that $\mathrm{O}_{2}$ limitation enhance the PHA production, as energy storage, until the cells retrieve more favourable conditions (Kourmentza et al., 2017).

After $72 \mathrm{~h}$ of culture, most of the conditions reached a plateau or a decline, with high growth (Figure S1A), which is a net improvement from the previous culturing method requiring more than 7 days. Interestingly, our result seems to indicate a faster growth on $\mathrm{H}_{2}$ than on acetate, while the Gibbs free energy of the reaction of acetate oxidation release more energy $\left(\Delta \mathrm{G}^{0}\right.$ Acetate $/ \mathrm{O}_{2}=-882 \mathrm{~kJ} \mathrm{~mol}^{-1}$ at $\left.60^{\circ} \mathrm{C}\right)$ than the hydrogen oxidation $\left(\Delta \mathrm{G}^{0} \mathrm{H}_{2} / \mathrm{O}_{2}=-261 \mathrm{~kJ}\right.$ $\mathrm{mol}^{-1}$ at $60^{\circ} \mathrm{C}$ ) (Amend and Shock, 2001). However, it is known that acetate needs an activation step by the Acetyl-coenzyme A synthetase, that catalyzes the ATP- and CoAdependent activation of acetate generating acetylCoA, AMP and pyrophosphate (acetate + ATP + CoA $\rightarrow$ acetyl-CoA $+\mathrm{AMP}+\mathrm{PP}_{\mathrm{i}}$ ) prior to enter the metabolism (Reiner et al., 2018b). In the hydrogenotrophic pathway, the $\mathrm{H}_{2}$ is directly converted into $\mathrm{H}^{+}$, used further by the ATP synthase to produce ATP (Brigham, 2019). This initial ATP consumption for acetate can explain the lag-time before growth in this condition. Similar results were observed in strains FAVT5 and COOX1, with doubling times of $3.6 \mathrm{~h}$ on $\mathrm{H}_{2}$ and $6 \mathrm{~h}$ on Acetate (Hogendoorn et al., 2020).

To better understand the effect of the media redox state and the ratio liquid/gas, the concentration of oxygen available in the serum bottles was calculated at $25^{\circ} \mathrm{C}$, which is the temperature of media preparation and inoculation. The dissolved oxygen during aerobic media preparation plays a minor role in the total oxygen amount, as only 6.4 and $12.8 \mu \mathrm{mol}$ of oxygen are present in $25 \mathrm{ml}$ and $50 \mathrm{ml}$ of media, respectively. However, the air flushed in the headspace of the bottle after autoclaving brings $0.799 \mathrm{mmol}$ and $0.564 \mathrm{mmol}$ of oxygen when the bottle is filled with $25 \mathrm{ml}$ and 50 $\mathrm{ml}$ of media, respectively. On the other hand, the reducing agent added to the anaerobic media preparation $(\mathrm{Cystein}-\mathrm{HCl})$, and in a minor part the redox indicator resazurin, will react with $\mathrm{O}_{2}$ and remove up to 0.079 and $0.160 \mathrm{mmol}$ in the $25 \mathrm{ml}$ and $50 \mathrm{ml}$ media, respectively.

The total $\mathrm{H}_{2}$ reaches 4.46 and 3.15 mmol with 25 $\mathrm{ml}$ and $50 \mathrm{ml}$ of media, respectively. Considering the stoichiometry of already reported Kyrpidia strains of 1 mole of $\mathrm{H}_{2}$ for 0.36 mole of $\mathrm{O}_{2}$, the availability of $\mathrm{O}_{2}$ is limiting in our condition (Hogendoorn et al., 2020). As the oxygen sensitivity of K. spormannii EA1 has not been evaluated yet, this difference of concentration can affect the growth significantly. Aquifex aeolicus, another microaerophilic (hyper)thermophilic bacteria, can grow with $\mathrm{O}_{2}$ concentration as low as 7.5 ppm (Deckert et al., 1998). Moreover, the volume ratio and the shaking influence the oxygen and hydrogen transfer to the liquid media during their consumption.

As previously mentioned, the difference of growth quantification by $\mathrm{OD}_{600 \mathrm{~nm}}$ measurement and by qPCR can be explained by the absorbance of PHA at $600 \mathrm{~nm}$. Figure S2-B represents the correlation between the 
OD $600 \mathrm{~nm}$ and the PHA measurement for the 3 different sampling times. At $t_{0}$, a poor correlation is observed, with $\mathrm{R}^{2}$ at 0.02 , but increase quickly above 0.81 after $24 \mathrm{~h}$, with a ratio converging to $28.4 \pm 6.78 \mathrm{mg} \cdot \mathrm{L}^{-1}$ of PHA per OD unit. Poorer correlations were observed between qPCR measurements and PHA quantification (Fig S2-C), with $\mathrm{R}^{2}$ at $0.22,0.47,0.79$ and 0.70 on samples after inoculation, $24 \mathrm{~h}, 48 \mathrm{~h}$, and $72 \mathrm{~h}$ respectively. The average ratio $\mathrm{PHA} / \mathrm{qPCR}$ were 16.0 , $10.1,6.9$ and $4.1 \mu \mathrm{g} \cdot \mathrm{cell}^{-1}$, at $0 \mathrm{~h}, 24 \mathrm{~h}, 48 \mathrm{~h}$ and $72 \mathrm{~h}$ respectively, indicating a divergence of energy into cell multiplication rather than to PHA production during the course of the culture.
Concerning the PHA production, Kourmentza et al. (2017) report PHA concentrations between 0.08 to 2.7 $\mathrm{g} \cdot \mathrm{L}^{-1}$ (based on reactor volume) produced by different strains using organic carbon sources. Comparatively, our production of PHA is relatively low (maximum of $29.3 \pm 1.2 \mathrm{mg} \cdot \mathrm{L}^{-1}$ ), and could probably be optimized by nutrient limitation, as previously described. Up to $90 \%$ of the dry cell mass can be composed of PHA (Verlinden et al., 2007). In our case, assuming a mass of $10^{-12} \mathrm{~g} \cdot \mathrm{cell}^{-1}$, we could theoretically reach $0.24 \mathrm{~g} \cdot \mathrm{L}^{-}$ ${ }^{1}$ of PHA, which would be in the lower range of previously reported product concentrations.

Table 2: Results of the ANOVA analysis obtained according to the experimental design with factors A: Shaking, B: Substrate, C: Media preparation, D: Ratio liquid/gas in the bottle. Three responses - the OD $600 \mathrm{~nm}$, the qPCR quantification and the PHA measurement - were considered at 3 times post inoculation on the average of triplicate experiments. The factors in red are main factors shown significant by the ANOVA test in the determination of the expected response. The factors in green are factors with a significant effect on the response when in interaction with other factors. The optimal conditions shown were defined by the ANOVA to maximize each response

\begin{tabular}{|c|c|c|c|c|c|c|c|c|c|}
\hline & \multicolumn{3}{|c|}{ Optimization OD $600 \mathrm{~nm}$} & \multicolumn{3}{|c|}{ Optimization qPCR } & \multicolumn{3}{|c|}{ Optimization PHA } \\
\hline & $24 \mathrm{~h}$ & $48 \mathrm{~h}$ & $72 \mathrm{~h}$ & $24 h$ & $48 \mathrm{~h}$ & $72 \mathrm{~h}$ & $24 \mathrm{~h}$ & $48 h$ & $72 \mathrm{~h}$ \\
\hline $\begin{array}{l}\text { Significant } \\
\text { factors }\end{array}$ & $\begin{array}{c}A, B, A B, \\
B C\end{array}$ & $B, A B D$ & $\begin{array}{c}A, B, D, \\
A D, B D, \\
A B D\end{array}$ & $\begin{array}{c}B, D, A D, \\
B C, B D\end{array}$ & $\begin{array}{c}B, D, \\
A D, B C, \\
B D\end{array}$ & $\begin{array}{l}B, C, D, \\
B C, B D\end{array}$ & $\begin{array}{c}A, B, C \\
A B, A C D\end{array}$ & $\begin{array}{l}B, D, A B, \\
A D, A B C, \\
A B D, A C D\end{array}$ & $\begin{array}{l}A, B, D \\
A D, A B D\end{array}$ \\
\hline $\mathrm{R}^{2}$ & 0.974 & 0.914 & 0.944 & 0.928 & 0.906 & 0.915 & 0.984 & 0.997 & 0.918 \\
\hline Adjusted $\mathrm{R}^{2}$ & 0.961 & 0.839 & 0.895 & 0.865 & 0.825 & 0.872 & 0.954 & 0.981 & 0.846 \\
\hline $\begin{array}{c}\text { Predicted } \\
\mathrm{R}^{2}\end{array}$ & 0.935 & 0.656 & 0.776 & 0.7129 & 0.627 & 0.782 & 0.845 & 0.843 & 0.672 \\
\hline \multirow[t]{2}{*}{$\begin{array}{c}\text { Adeq } \\
\text { Precision }\end{array}$} & 22.5 & 10.2 & 14.1 & 13.1 & 11.3 & 14.9 & 17.9 & 25.0 & 10.6 \\
\hline & \multicolumn{9}{|c|}{ Optimal conditions } \\
\hline A: Shaking & Yes & Yes & No & Yes & No & - & Yes & Yes & No \\
\hline $\begin{array}{c}\text { B: } \\
\text { Substrate }\end{array}$ & $\mathrm{H}_{2}: \mathrm{CO}_{2}$ & $\mathrm{H}_{2}: \mathrm{CO}_{2}$ & Acetate & $\mathrm{H}_{2}: \mathrm{CO}_{2}$ & Acetate & Acetate & $\mathrm{H}_{2}: \mathrm{CO}_{2}$ & $\mathrm{H}_{2}: \mathrm{CO}_{2}$ & Acetate \\
\hline $\begin{array}{c}\text { C: Media } \\
\text { prep. }\end{array}$ & Anaerobic & - & - & Anaerobic & Aerobic & Aerobic & Anaerobic & Anaerobic & - \\
\hline $\begin{array}{l}\text { D: Ratio } \\
\text { liq/gas }\end{array}$ & - & $25 / 85$ & $25 / 85$ & $50 / 60$ & $25 / 85$ & $25 / 85$ & $25 / 85$ & $25 / 85$ & $25 / 85$ \\
\hline $\begin{array}{c}\text { Expected } \\
\text { results }\end{array}$ & 0.312 & 0.754 & 0.983 & 7.23 & 7.80 & 8.40 & 14.9 & 19.2 & 26.4 \\
\hline Unit & \multicolumn{3}{|c|}{$\mathrm{OD}_{600 \mathrm{~nm}}$} & \multicolumn{3}{|c|}{ Log10 cells $/ \mathrm{ml}$} & \multicolumn{3}{|c|}{$\mathrm{mg} / \mathrm{l}$} \\
\hline
\end{tabular}




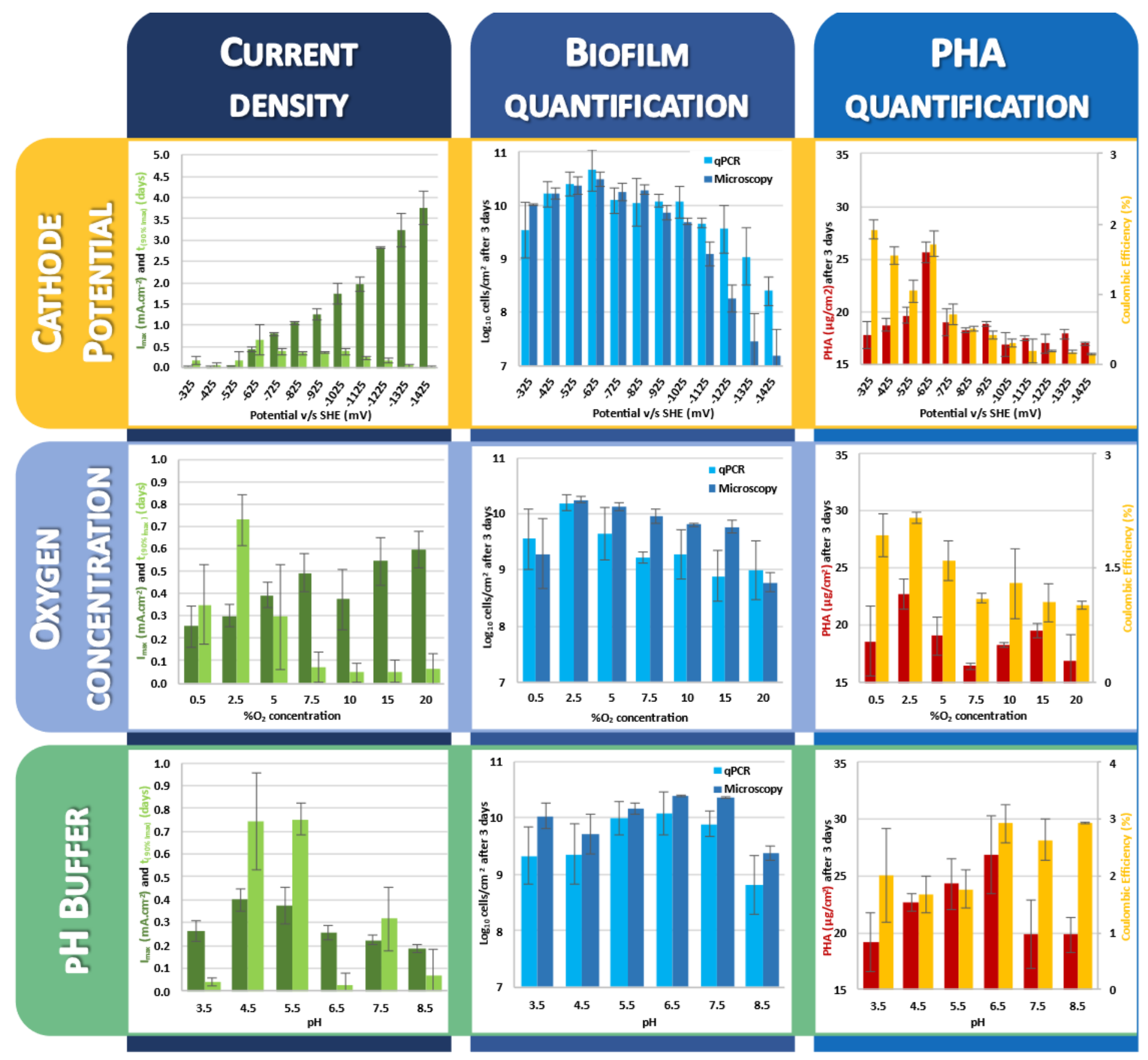

Figure 1: Results of current consumption, lag time, microscopic and qPCR quantifications, PHA production and coulombic efficiency for the optimization of the cathode potential, the oxygen concentration in the MES and the pH of the buffered media. The data presented here are the results of experimental triplicates.

\section{Optimization of biofilm formation by Kyrpidia spormannii growing on a cathode}

Three factors were considered in this study for the optimization of biofilm formation on the cathode: the cathode potential, the oxygen concentration of the sparging of the media, and the $\mathrm{pH}$ of the buffered media. The initial conditions were a potential of $525 \mathrm{mV}, \mathrm{O}_{2}$ concentration of $5 \%$ and a $\mathrm{pH}$ of 5.5 . The current consumption was recorded over 2.8 days, with a plateau after 1 to 2 days, allowing to calculate a stabilized current value for further consideration. The Figure 1 shows the results obtained on the maximum stabilized current consumption, the lag time before obtaining $90 \%$ of this stabilized current, the biofilm quantification at the end of the experiment by microscopy and qPCR and the PHA quantification and coulombic efficiency associated. 

available under aCC-BY-NC 4.0 International license.

\section{Optimization of cathode potential}

The potential screening exhibit two different behaviours over two separate range of potentials (Figure 1, dark-green histograms in the first horizontal panel, Supplementary figure 3 ). At the most positive potentials, from -325 to $-525 \mathrm{mV}$ vs. SHE, no clear trend is observed with current density around 0.03 $\mathrm{mA} \cdot \mathrm{cm}^{-2}$, while at lower potential, we can see an exponential increase of the maximum current $\left(\mathrm{R}^{2}=0.975\right)$, from $0.44 \mathrm{~mA} \cdot \mathrm{cm}^{-2}$ at $-625 \mathrm{mV}$ vs SHE to $3.77 \mathrm{~mA} \cdot \mathrm{cm}^{-2}$ at $-1425 \mathrm{mV}$. This increase of current while decreasing the potential is expected by the abiotic reduction of the oxygen on the graphite electrode, with standard potential at $60^{\circ} \mathrm{C}$ and $\mathrm{pH} 5.5$ estimated at $1.10 \mathrm{~V}$ vs. SHE (according to coefficients in Bratsch, 1989). It is then difficult to dissociate the abiotic reaction to the biotic activity of the biofilm. However, the lag-time (Figure 1, light-green histograms in the first horizontal panel) to reach this maximum current is a proxy of the biofilm growth. Indeed, the system is at equilibrium when inoculating the reactor, then, the only increase of current expected is due to biofilm formation, observed by microscopy.
This lag time increases to around 0,37 days between 725 and $-1025 \mathrm{mV}$ vs. SHE, with a peak at $0,65 \pm 0,36$ days for $-625 \mathrm{mV}$ vs. SHE.

The quantification of the biofilm at the end of the experiment (Figure 1 and 2) indicates a preference for more positive potential, with an increase from 9.5 $\log _{10}$ cells $\cdot \mathrm{cm}^{-2}$ of electrode at $-325 \mathrm{mV}$ vs. SHE to the maximum of 10.5 at $-625 \mathrm{mV}$ vs. SHE, followed by a decrease down to $8.4 \log _{10}$ ells $\cdot \mathrm{cm}^{-2}$ at $-1425 \mathrm{mV}$ vs. SHE on microscopic cell counting. A slight deviation of quantification is observed with the qPCR method, with higher values, probably indicating the death of a part of the biofilm at low potential, not observed in microscopy, but which DNA remains attached to the electrode and quantified by qPCR. This would be corroborated by the known production of toxic $\mathrm{H}_{2} \mathrm{O}_{2}$ or other radicals from two-electron oxygen reduction at low potentials (Pang et al., 2020). Indeed, the $\mathrm{H}_{2} \mathrm{O}_{2}$ production on graphite material was previously reported between -900 to $-400 \mathrm{mV}$ vs. SHE in pure oxygen atmosphere, with faradaic efficiency decreasing from $80 \%$ to $25 \%$ when the potential is more negative (Da Pozzo et al., 2005). However,

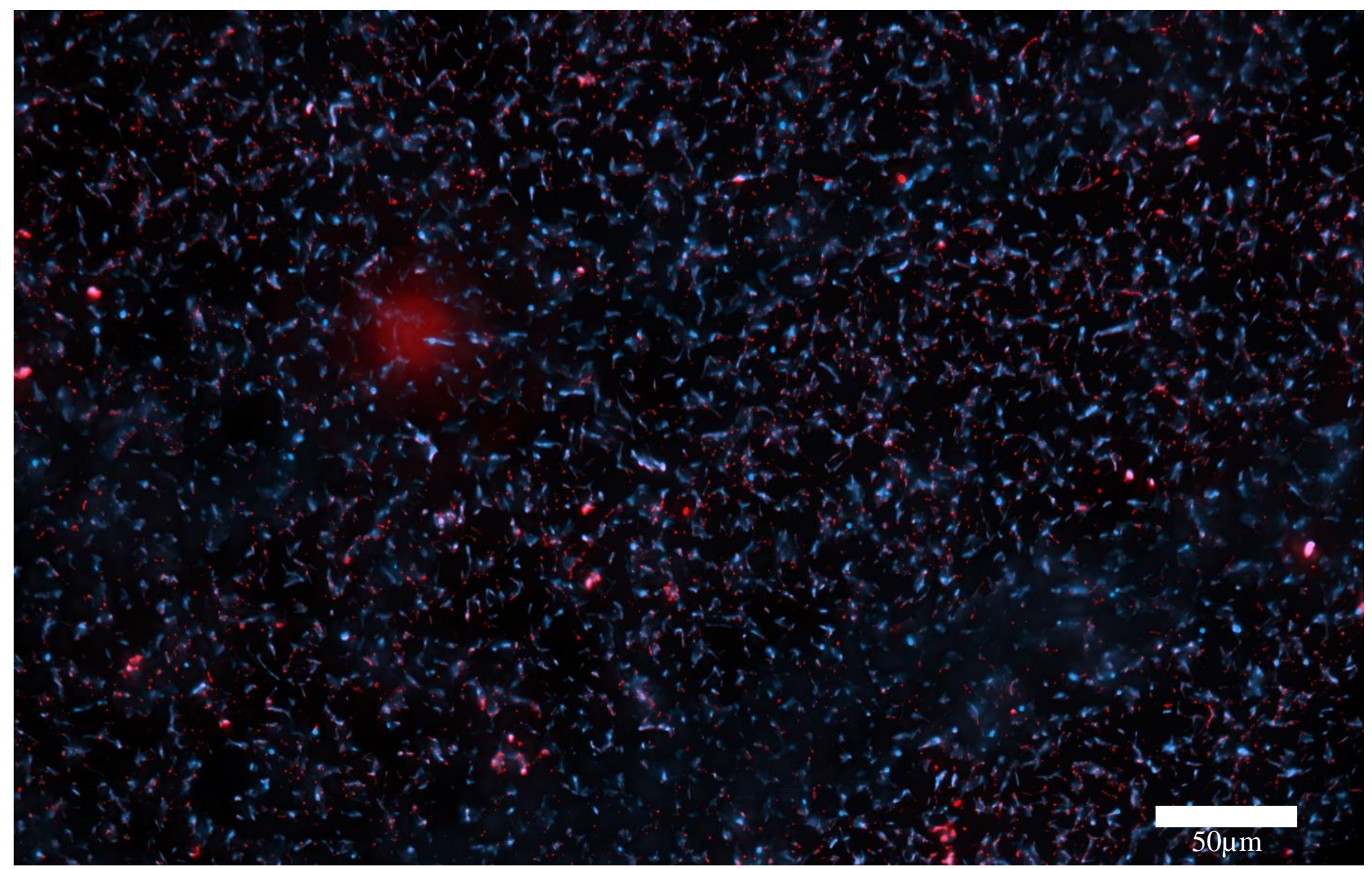

Figure 2: Example of microscopic observation of Kyrpidia spormannii EA-1 biofilm on the cathode surface. The blue signal represents the staining of DNA with DAPI, the red signal represents the staining of PHA with NileRed. 
considering the increase of current at low potential, the total amount of $\mathrm{H}_{2} \mathrm{O}_{2}$ is expected to be higher than at more positive potential, leading to increased death of cells in the biofilm.

A similar effect in observed on the PHA production, with increase from 17.8 to $25.6 \mu \mathrm{g} \cdot \mathrm{cm}^{-2}$ between -325 to $-625 \mathrm{mV}$, followed by a decrease down to $17.0 \mu \mathrm{g} \cdot \mathrm{cm}^{-2}$ at $-1425 \mathrm{mV}$. The coulombic efficiency was calculated at $1.9 \%$ at $-325 \mathrm{mV}$ decreasing to $0.2 \%$ at $-1425 \mathrm{mV}$, with a peak up to $1.7 \%$ at $-625 \mathrm{mV}$. This effect can be explained by the abiotic reaction of oxygen at lower potential, diverging electrons from the cathode to the formation of $\mathrm{H}_{2} \mathrm{O}$ or $\mathrm{H}_{2} \mathrm{O}_{2}$ molecules.

The overall PHA production is relatively low compared to the cells attached to the electrode, with a ratio at only $9.0 \cdot 10^{-9} \mu \mathrm{g} \cdot \mathrm{cell}^{-1}$ (versus $4.1 \mu \mathrm{g} \cdot \mathrm{cell}^{-1}$ in liquid media). This could be explained by an insufficient detachment step of the PHA by sonication of the biofilm, but microscopy of the electrode after sonication didn't show any signal with Nile Red staining. It could also be explained by the higher availability of electron donor and acceptor in the MES, with constant electron flow from the cathode and oxygen flow from the gas bubbling. Indeed, in presence of sufficient electron donor and acceptor, the cells proliferate and doesn't accumulate much PHA. According to the cell concentration and assuming a yield of $90 \%$ of the dry mass as PHA, we could theoretically reach $3.4 \mathrm{mg}$ of PHA per $\mathrm{cm}^{2}$ of cathode (versus $25.6 \mu \mathrm{g} \cdot \mathrm{cm}^{-2}$ in our conditions). The potential of $-625 \mathrm{mV}$ vs. SHE was then selected for further experiments, as it presented the best biofilm growth, the highest PHA production and one of the highest coulombic efficiency.

\section{Optimization of oxygen concentration}

Looking at the oxygen effect on biofilm growth and PHA production, presented Figure 1, we can see an overall trend with the increase of current consumption from $0.25 \mathrm{~mA} \cdot \mathrm{cm}^{-2}$ to $0.59 \mathrm{~mA} \cdot \mathrm{cm}^{-2}$ while increasing the oxygen concentration from $0.5 \%$ up to $20 \%$. However, the lag time (Figure 1, light-green histograms in the second horizontal panel) to achieve this maximum current consumption present a bell curve with a maximum of 0.73 days at $2.5 \%$. At concentration higher than $5 \%$, this delay is reduced to around 0.06 days. This really short delay $(1.4 \mathrm{~h})$ is most likely not the result of a microbial growth as it is shorter that the optimal generation time of $3.6 \mathrm{~h}$ reported for Kyrpidia strains (Hogendoorn et al.,
2020) on $\mathrm{H}_{2}$ : $\mathrm{CO}_{2}$. Thus, we can assume that most part of this current consumption is due to abiotic oxygen reduction, especially when increasing $\mathrm{O}_{2}$ concentration. The quantification of the biofilm exhibits a similar trend, both in microscopic or qPCR quantification, with maximum biofilm density observed at $2.5 \%$ with around $10.2 \log 10$ cells $\cdot \mathrm{cm}^{-2}$, decreasing down to $8.7-9.0 \log _{10}$ cells $\cdot \mathrm{cm}^{-2}$ at $20 \%$. Looking at the PHA production, an optimum of 22.7 $\mu \mathrm{g} \cdot \mathrm{cm}^{-2}$ is also observed at $2.5 \% \mathrm{O}_{2}$, with higher CE up to $2.17 \%$. These values decrease to $16.8 \mu \mathrm{g} \cdot \mathrm{cm}^{-2}$ and $1.02 \%$ at $20 \% \mathrm{O}_{2}$. No increase of PHA production was observed at lower concentration, as expected by the limitation of electron acceptor previously reported in other PHA producers (Kourmentza et al., 2017). Then we can conclude that the optimal $\mathrm{O}_{2}$ concentration for $K$. spormanni EA-1 is $2.5 \%$ amongst the tested conditions in this work, in agreement with the microaerophilic preference previously reported (Reiner et al., 2018a). The optimal $\mathrm{O}_{2}$ concentration for Kyrpidia strains in liquid culture is still unknown, but similar $\mathrm{O}_{2}$ optimum of $2.5 \%$ was observed in other Knallgas bacteria, such as Mycobacterium genavense (Realini et al., 1998).

\section{Optimization of $\mathrm{pH}$ of buffered media}

Once the optimal potential and $\mathrm{O}_{2}$ concentration were identified, the effect of the $\mathrm{pH}$ of the media was studied. As Kyrpidia was described as acidophilic, the pH was tested between 3.5 and 8.5. Results associated are presented Figure 1. Looking at the current consumption, a bell curve shape is observed with a maximum at $0.40 \mathrm{~mA} \cdot \mathrm{cm}^{-2}$ at $\mathrm{pH} 4.5$, decreasing down to $0.19 \mathrm{~mA} \cdot \mathrm{cm}^{-2}$ at $\mathrm{pH} 8.5$. The delay before stabilization of the current was however more chaotic, with high values around 0.74 days at $\mathrm{pH} 4.5$ and 5.5,

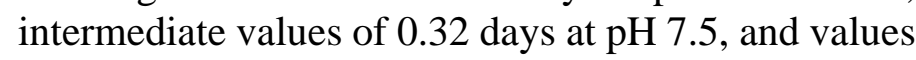
below 0.07 days at $\mathrm{pH} 3.5,6.5$ and 8.5. The biofilm quantification shows variation of only $1 \log _{10}$ between the different $\mathrm{pH}$, with optimum of 10.1-10.4 $\log _{10}$ cells $\mathrm{cm}^{-2}$ at $\mathrm{pH}$ 6.5, decreasing at 8.8-9.4 $\log _{10}$ cells $\cdot \mathrm{cm}^{-2}$ at $\mathrm{pH}$ 8.5. Finally, the PHA quantification exhibit also a maximum at $\mathrm{pH} 6.5$ with $26.8 \mu \mathrm{g} \cdot \mathrm{cm}^{-2}$ produced with a CE of $2.93 \%$. The PHA production decrease slowly to $19.2 \mu \mathrm{g} \cdot \mathrm{cm}^{-2}$ when decreasing the $\mathrm{pH}$ to 3.5 and quickly to $19.8 \mu \mathrm{g} \cdot \mathrm{cm}^{-2}$ when increasing the $\mathrm{pH}$ to 7.5-8.5. Thus, an optimum biofilm growth and PHA production is observed at $\mathrm{pH}$ 6.5 .

The production rate obtained after optimizing the growth conditions reached $96 \mathrm{mg} \cdot \mathrm{day}^{-1} \cdot \mathrm{m}^{-2}$. This value 
remains relatively low compared to industrial production of PHA from feedstock. However, as previously mentioned, any substrate limitation step was applied here, as the main goal of this work was to produce a dense biofilm prior to this PHA accumulation phase. Further work on substrate limitation of the formed biofilm will allow to more accurately evaluate the industrial potentiality of this new technology.

\section{CONCLUSION}

This study aimed at identifying the optimal conditions for the growth of Kyrpidia spormannii EA1 either in liquid preculture or on the cathode of a Microbial Electrosynthesis System. The results allowed to reduce the culture time from 7 days to $48 \mathrm{~h}$ by optimizing the substrate, the incubation condition and the media preparation. These results are particularly relevant for the synthesis of PHA in liquid media through lithoauto- or hetero-trophy. The growth of the biofilm was optimized and shows maximum growth of $10.4 \mathrm{Log}_{10}$ cells $\mathrm{cm}^{-2}$ and PHA production of $26.8 \mu \mathrm{g} \cdot \mathrm{cm}^{-2}$ or $96 \mathrm{mg} \cdot \mathrm{day}^{-1} \cdot \mathrm{m}^{-2}$ at $-625 \mathrm{mV}$ vs. SHE, $2.5 \% \mathrm{O}_{2}$ atmosphere, and a $\mathrm{pH}$ of 6.5. These conditions are a starting point to study the effect of nutrient limitation on the formed biofilm for the PHA accumulation in future works. Also, we expect that further optimization of the cathode material and surface modification could increase the initial biofilm growth and PHA production. Only after these optimizations, a meaningful evaluation of the competitiveness of this process for the industrial production of PHA, compared to the heterotrophic or hydrogenotrophic pathways of other PHA producers, will be possible.

\section{CONFLICTS OF INTEREST}

There are no conflicts to declare.

\section{ACKNOWLEDGEMENTS}

We are grateful for the financial support from the German Ministry of Education and Research (BMBF) under the program 033RC006B.

\section{REFERENCES}

Alqahtani, M.F., Bajracharya, S., Katuri, K.P., Ali, M., Ragab, A., Michoud, G., Daffonchio, D., Saikaly,
P.E., 2019. Enrichment of Marinobacter sp. and Halophilic Homoacetogens at the Biocathode of Microbial Electrosynthesis System Inoculated With Red Sea Brine Pool. Front. Microbiol. 10, 2563.

https://doi.org/10.3389/fmicb.2019.02563

Amend, J.P., Shock, E.L., 2001. Energetics of overall metabolic reactions of thermophilic and hyperthermophilic Archaea and Bacteria. FEMS Microbiol. Rev. 25, 175-243. https://doi.org/10.1111/j.15746976.2001.tb00576.x

Bratsch, S.G., 1989. Standard Electrode Potentials and Temperature Coefficients in Water at 298.15 K. J. Phys. Chem. Ref. Data 18, 1-21. https://doi.org/10.1063/1.555839

Brigham, C., 2019. Perspectives for the biotechnological production of biofuels from $\mathrm{CO}$ 2 and $\mathrm{H} 2$ using Ralstonia eutropha and other 'Knallgas' bacteria. Appl. Microbiol. Biotechnol. https://doi.org/10.1007/s00253-019-09636-y

Coker, J.A., 2016. Extremophiles and biotechnology: Current uses and prospects. F1000Research. https://doi.org/10.12688/f1000research.7432.1

Da Pozzo, A., Di Palma, L., Merli, C., Petrucci, E., 2005. An experimental comparison of a graphite electrode and a gas diffusion electrode for the cathodic production of hydrogen peroxide. J. Appl. Electrochem. 35, 413-419. https://doi.org/10.1007/S10800-005-0800-2

Deckert, G., Warren, P. V., Gaasterland, T., Young, W.G., Lenox, A.L., Graham, D.E., Overbeek, R., Snead, M.A., Keller, M., Aujay, M., Huber, R., Feldman, R.A., Short, J.M., Olsen, G.J., Swanson, R. V., 1998. The complete genome of the hyperthermophilic bacterium Aquifex aeolicus. Nature 392, 353-358. https://doi.org/10.1038/32831

Erben, J., Wang, X., Kerzenmacher, S., 2021. High current production of Shewanella oneidensis with electrospun carbon nanofiber anodes is directly linked to biofilm formation. bioRxiv 8, 2021.01.28.428465.

https://doi.org/10.1101/2021.01.28.428465

Faraghiparapari, N., Zengler, K., 2017. Production of 
organics from $\mathrm{CO} 2$ by microbial electrosynthesis (MES) at high temperature. J. Chem. Technol. Biotechnol. 92, 375-381. https://doi.org/10.1002/JCTB.5015

Hogendoorn, C., Pol, A., Picone, N., Cremers, G., van Alen, T.A., Gagliano, A.L., Jetten, M.S.M., D’Alessandro, W., Quatrini, P., Op den Camp, H.J.M., 2020. Hydrogen and Carbon MonoxideUtilizing Kyrpidia spormannii Species From Pantelleria Island, Italy. Front. Microbiol. 11. https://doi.org/10.3389/fmicb.2020.00951

Islam Mozumder, M.S., Garcia-Gonzalez, L., Wever, H. De, Volcke, E.I.P., 2015. Poly(3-hydroxybutyrate) (PHB) production from CO2: Model development and process optimization. Biochem. Eng. J. 98, 107-116. https://doi.org/10.1016/j.bej.2015.02.031

Jourdin, L., Burdyny, T., 2021. Microbial Electrosynthesis: Where Do We Go from Here? Trends Biotechnol. https://doi.org/10.1016/j.tibtech.2020.10.014

Jourdin, L., Raes, S.M.T., Buisman, C.J.N., Strik, D.P.B.T.B., 2018. Critical biofilm growth throughout unmodified carbon felts allows continuous bioelectrochemical chain elongation from $\mathrm{CO} 2$ up to caproate at high current density. Front. Energy Res. 6, 1. https://doi.org/10.3389/fenrg.2018.00007

Kourmentza, C., Plácido, J., Venetsaneas, N., BurniolFigols, A., Varrone, C., Gavala, H.N., Reis, M.A.M., 2017. Recent advances and challenges towards sustainable polyhydroxyalkanoate (PHA) production. Bioengineering. https://doi.org/10.3390/bioengineering402005 5

Kracke, F., Lai, B., Yu, S., Krömer, J.O., 2018. Balancing cellular redox metabolism in microbial electrosynthesis and electro fermentation - A chance for metabolic engineering. Metab. Eng. https://doi.org/10.1016/j.ymben.2017.12.003

Lovley, D.R., Nevin, K.P., 2011. A shift in the current: New applications and concepts for microbeelectrode electron exchange. Curr. Opin. Biotechnol. https://doi.org/10.1016/j.copbio.2011.01.009
Obruca, S., Sedlacek, P., Slaninova, E., Fritz, I., Daffert, C., Meixner, K., Sedrlova, Z., Koller, M., 2020. Novel unexpected functions of PHA granules. Appl. Microbiol. Biotechnol. https://doi.org/10.1007/s00253-020-10568-1

Pang, Y., Xie, H., Sun, Y., Titirici, M.M., Chai, G.L., 2020. Electrochemical oxygen reduction for H2O2production: Catalysts, $\mathrm{pH}$ effects and mechanisms. J. Mater. Chem. A. https://doi.org/10.1039/d0ta09122g

Panuschka, S., Drosg, B., Ellersdorfer, M., Meixner, K., Fritz, I., 2019. Photoautotrophic production of poly-hydroxybutyrate - First detailed cost estimations. Algal Res. 41, 101558. https://doi.org/10.1016/J.ALGAL.2019.101558

Pillot, G., Davidson, S., Shintu, L., Ali, O.A., Godfroy, A., Combet-Blanc, Y., Bonin, P., Liebgott, P.P., 2020. Electrotrophy as potential primary metabolism for colonization of conductive surfaces in deep-sea hydrothermal chimneys. bioRxiv.

https://doi.org/10.1101/2020.11.11.377697

Pillot, G., Davidson, S., Shintu, L., Tanet, L., CombetBlanc, Y., Godfroy, A., Bonin, P., Liebgott, P.-P., 2021. Thriving of hyperthermophilic microbial communities from a deep-sea sulfidic hydrothermal chimney under electrolithoautotrophic conditions with nitrate as electron acceptor. bioRxiv 2021.03.26.437165.

https://doi.org/10.1101/2021.03.26.437165

Prévoteau, A., Carvajal-Arroyo, J.M., Ganigué, R., Rabaey, K., 2020. Microbial electrosynthesis from CO2: forever a promise? Curr. Opin. Biotechnol.

https://doi.org/10.1016/j.copbio.2019.08.014

Rabaey, K., Rozendal, R.A., 2010. Microbial electrosynthesis - Revisiting the electrical route for microbial production. Nat. Rev. Microbiol. https://doi.org/10.1038/nrmicro2422

Realini, L., De Ridder, K., Palomino, J.C., Hirschel, B., Portaels, F., 1998. Microaerophilic conditions promote growth of Mycobacterium genavense. J. Clin. Microbiol. 36, 2565-2570. https://doi.org/10.1128/jcm.36.9.25652570.1998 
Reiner, J.E., Geiger, K., Hackbarth, M., Fink, M., Lapp, C.J., Jung, T., Dötsch, A., Hügler, M., Wagner, M., Hille-Reichel, A., Wilcke, W., Kerzenmacher, S., Horn, H., Gescher, J., 2020. From an extremophilic community to an electroautotrophic production strain: identifying a novel Knallgas bacterium as cathodic biofilm biocatalyst. ISME J. 14, 1125-1140. https://doi.org/10.1038/s41396-020-0595-5

Reiner, J.E., Jung, T., Lapp, C.J., Siedler, M., Bunk, B., Overmann, J., Gescher, J., 2018a. Kyrpidia spormannii sp. nov., a thermophilic, hydrogenoxidizing, facultative autotroph, isolated from hydrothermal systems at São Miguel Island, and emended description of the genus Kyrpidia. Int. J. Syst. Evol. Microbiol. 68, 3735-3740.

https://doi.org/10.1099/ijsem.0.003037

Reiner, J.E., Lapp, C.J., Bunk, B., Spröer, C., Overmann, J., Gescher, J., 2018b. Complete genome sequence of Kyrpidia sp. strain EA-1, a thermophilic knallgas bacterium, isolated from the Azores. Genome Announc. 6. https://doi.org/10.1128/genomeA.01505-17

Selinummi, J., Seppälä, J., Yli-Harja, O., Puhakka, J.A., 2005. Software for quantification of labeled bacteria from digital microscope images by automated image analysis. Biotechniques 39, 859-862. https://doi.org/10.2144/000112018

Uzarraga, R., Auria, R., Davidson, S., Navarro, D., Combet-Blanc, Y., 2011. New cultural approaches for Microaerophilic Hyperthermophiles. Curr. Microbiol. 62, 346350. https://doi.org/10.1007/s00284-010-97124

Vassilev, I., Kracke, F., Freguia, S., Keller, J., Krömer, J.O., Ledezma, P., Virdis, B., 2019. Microbial electrosynthesis system with dual biocathode arrangement for simultaneous acetogenesis, solventogenesis and carbon chain elongation. Chem. Commun. 55, 4351-4354. https://doi.org/10.1039/c9cc00208a

Verlinden, R.A.J., Hill, D.J., Kenward, M.A., Williams, C.D., Radecka, I., 2007. Bacterial synthesis of biodegradable polyhydroxyalkanoates. J. Appl. Microbiol. https://doi.org/10.1111/j.1365-

\subsubsection{5.x}

Watanabe, Y., Ichinomiya, Y., Shimada, D., Saika, A., Abe, H., Taguchi, S., Tsuge, T., 2012. Development and validation of an HPLC-based screening method to acquire polyhydroxyalkanoate synthase mutants with altered substrate specificity. J. Biosci. Bioeng. 113, 286-292. https://doi.org/10.1016/j.jbiosc.2011.10.015

Wolin, E.A., Wolin, M.J., Wolfe, R.S., 1963. Formation of methane by bacterial extracts. J. Biol. Chem. 238, 2882-2886. https://doi.org/10.1016/s0021-9258(18)679128 


\section{SUPPLEMENTARY INFORMATION}
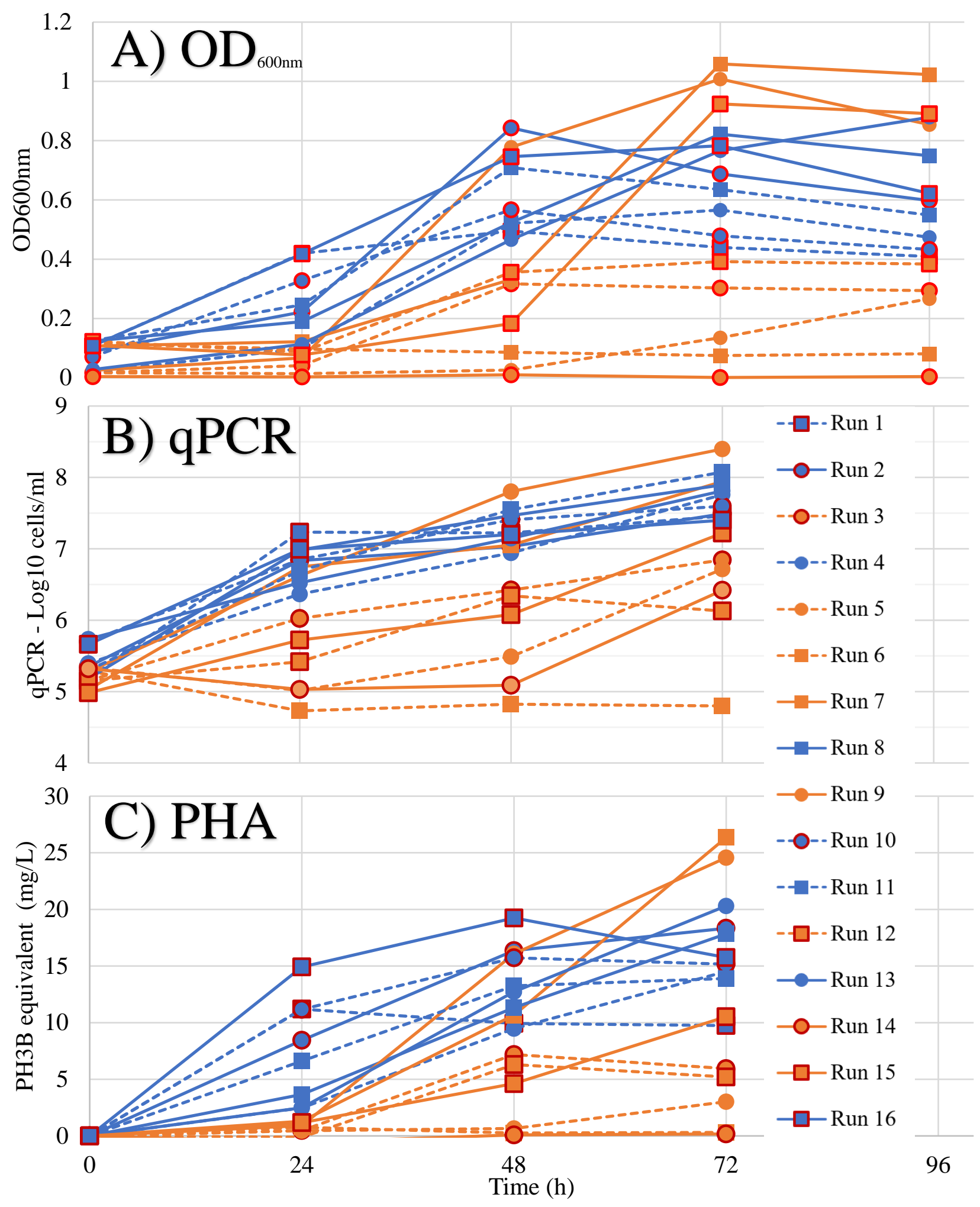

Supplementary Figure 1: A) average $\mathrm{OD}_{600 \mathrm{~nm}}$, B) average qPCR quantification and C) average PHA quantification of triplicates obtained in the 16 runs of the Design of Experiment. Red contour = Shaking; No contour = no Shaking; Blue lines $=\mathrm{H}_{2}: \mathrm{CO}_{2} ;$ Orange lines = Acetate; Squares $=\mathrm{N}_{2}$ media preparation, Circles $=$ $\mathrm{O}_{2}$ media preparation; Plain lines $=$ ratio 25/85; Dot lines $=$ ratio 50/60. 
bioRxiv preprint doi: https:/doi.org/10.1101/2021.10.25.465696; this version posted October 25, 2021. The copyright holder for this preprint (which was not certified by peer review) is the author/funder, who has granted bioRxiv a license to display the preprint in perpetuity. It is made available under aCC-BY-NC 4.0 International license.

Supplementary Table 1: Coefficients table of each factor and interaction included in the ANOVA model, with associated p-value. Values in red are significant model terms.

\begin{tabular}{|c|c|c|c|c|c|c|c|c|c|c|c|c|c|c|}
\hline & Intercept & A & B & C & D & AB & AC & AD & BC & BD & CD & ABC & ABD & ACD \\
\hline OD24h & 0.0908125 & $\begin{array}{l}- \\
0.0425625\end{array}$ & 0.0919375 & 0.0013125 & & 0.0526875 & & & 0.0179375 & & & & & \\
\hline$p$-values & & $<0.0001$ & $<0.0001$ & 0.8284 & & $<0.0001$ & & & 0.0124 & & & & & \\
\hline OD48h & 0.348062 & $\begin{array}{r}- \\
0.0129375\end{array}$ & -0.176687 & & $\begin{array}{r}- \\
0.0379375\end{array}$ & 0.0310625 & & 0.0309375 & & 0.0051875 & & & $\begin{array}{r}- \\
0.125437\end{array}$ & \\
\hline p-values & & 0.6097 & $<0.0001$ & & 0.1579 & 0.2379 & & 0.2396 & & 0.8366 & & & 0.0009 & \\
\hline OD72h & 0.487 & 0.076125 & -0.07625 & & -0.183375 & 0.016375 & & -0.09625 & & -0.069125 & & & -0.1155 & \\
\hline p-values & & 0.0112 & 0.0111 & & $<0.0001$ & 0.5007 & & 0.0032 & & 0.0177 & & & 0.0011 & \\
\hline qPCR24h & 6.33568 & -0.12605 & -0.473542 & 0.0211864 & -0.294625 & & & -0.214192 & -0.186941 & -0.270464 & & & & \\
\hline p-values & & 0.1022 & 0.0001 & 0.7643 & 0.0026 & & & 0.0139 & 0.0256 & 0.0042 & & & & \\
\hline qPCR48h & 6.86071 & -0.077208 & -0.384647 & -0.14466 & -0.373705 & & & -0.208833 & -0.258029 & -0.407826 & & & & \\
\hline p-values & & 0.4015 & 0.0022 & 0.1355 & 0.0027 & & & 0.0434 & 0.0181 & 0.0016 & & & & \\
\hline qPCR72h & 7.43325 & & -0.252373 & -0.193156 & -0.38614 & & & & -0.214765 & -0.422631 & & & & \\
\hline p-values & & & 0.0035 & 0.0156 & 0.0002 & & & & 0.0089 & $<0.0001$ & & & & \\
\hline PHA24h & 4.08385 & -1.75164 & -3.53669 & 0.853453 & 0.0444391 & 2.05968 & 0.102823 & 0.198316 & -0.621802 & & 0.370175 & & & 0.728264 \\
\hline$p$-values & & 0.0010 & $<0.0001$ & 0.0210 & 0.8696 & 0.0005 & 0.7058 & 0.4755 & 0.0603 & & 0.2096 & & & 0.0366 \\
\hline PHA48h & 9.61721 & -0.314248 & -3.88611 & -0.168951 & -1.77043 & 1.49753 & 0.259901 & -1.62439 & -0.102226 & -0.360546 & $\begin{array}{r}- \\
0.243937\end{array}$ & 0.920245 & -2.7015 & 1.51758 \\
\hline p-values & & 0.2639 & 0.0028 & 0.4953 & 0.0131 & 0.0181 & 0.3313 & 0.0155 & 0.6665 & 0.2197 & 0.3549 & 0.0459 & 0.0057 & 0.0176 \\
\hline PHA72h & 12.6036 & 2.49875 & -3.09133 & & -4.12745 & 1.55219 & & -3.03736 & & -1.76443 & & & -2.96805 & \\
\hline$p$-values & & 0.0135 & 0.0045 & & 0.0008 & 0.0858 & & 0.0050 & & 0.0566 & & & 0.0057 & \\
\hline
\end{tabular}


bioRxiv preprint doi: https://doi.org/10.1101/2021.10.25.465696; this version posted October 25, 2021. The copyright holder for this preprint (which was not certified by peer review) is the author/funder, who has granted bioRxiv a license to display the preprint in perpetuity. It is made available under aCC-BY-NC 4.0 International license.

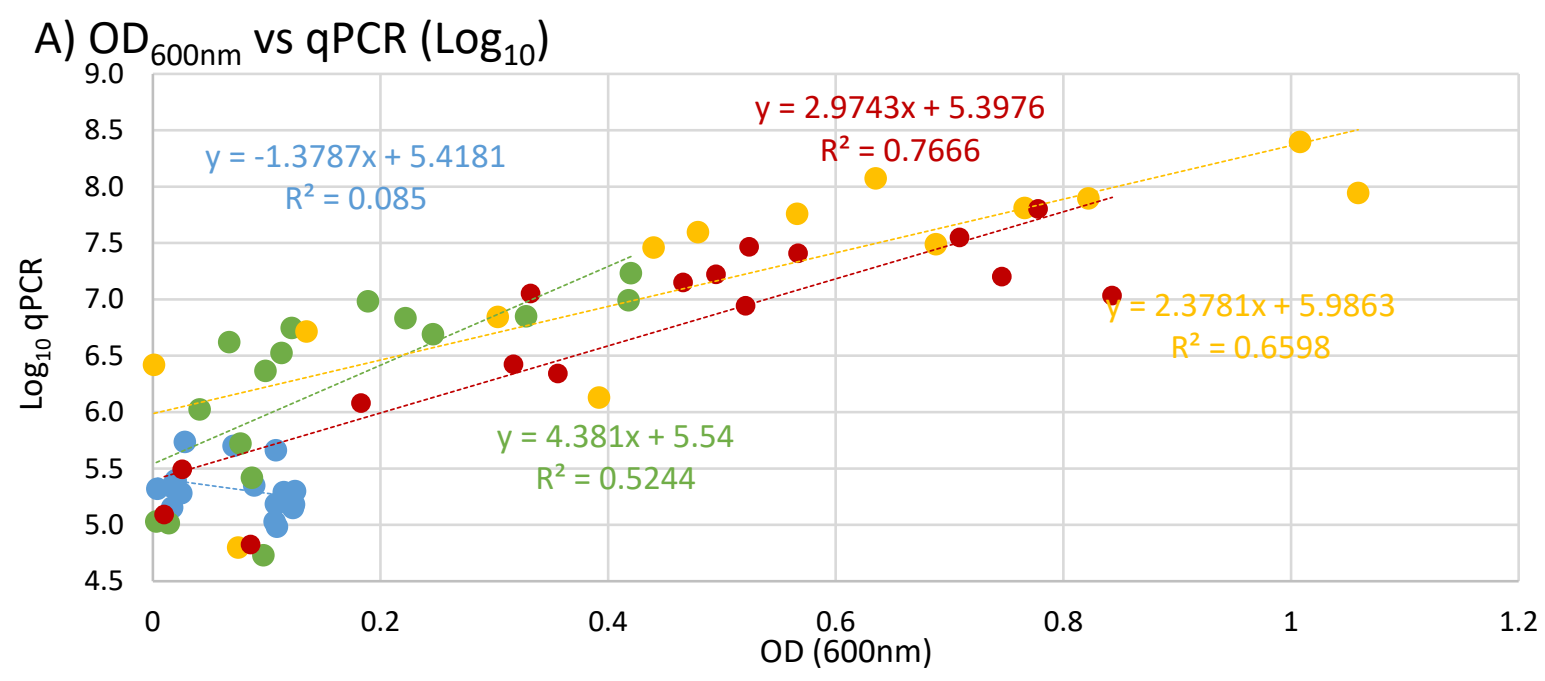

\section{B) $\mathrm{OD}_{600 \mathrm{~nm}}$ vs PHA}
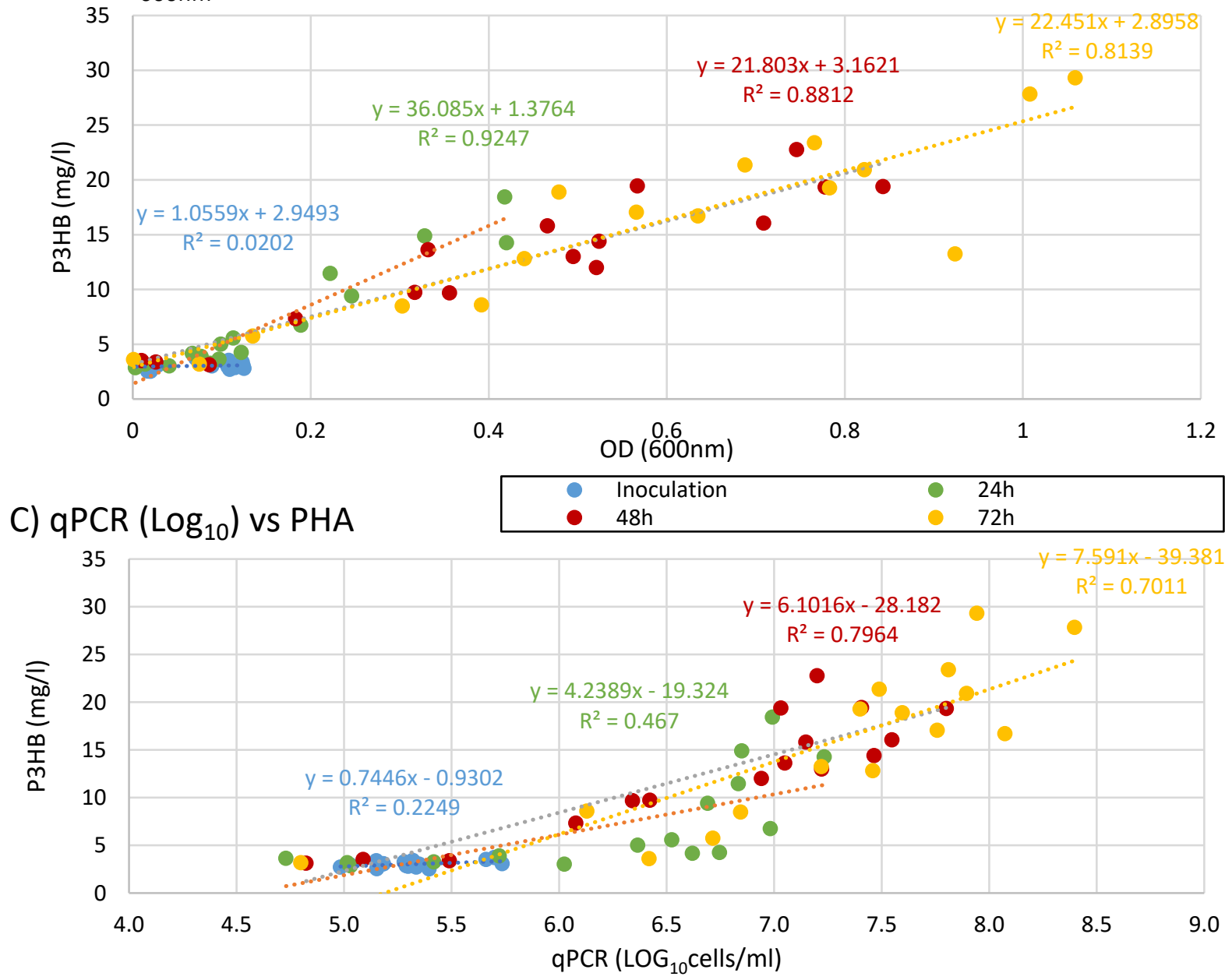

Supplementary Figure 2: Correlation between A) OD600nm measurements and qPCR quantification, B) OD600nm measurements and PHA production and C) qPCR measurement and PHA production, in Kyrpidia spormannii. 
bioRxiv preprint doi: https://doi.org/10.1101/2021.10.25.465696; this version posted October 25, 2021. The copyright holder for this preprint (which was not certified by peer review) is the author/funder, who has granted bioRxiv a license to display the preprint in perpetuity. It is made available under aCC-BY-NC 4.0 International license.

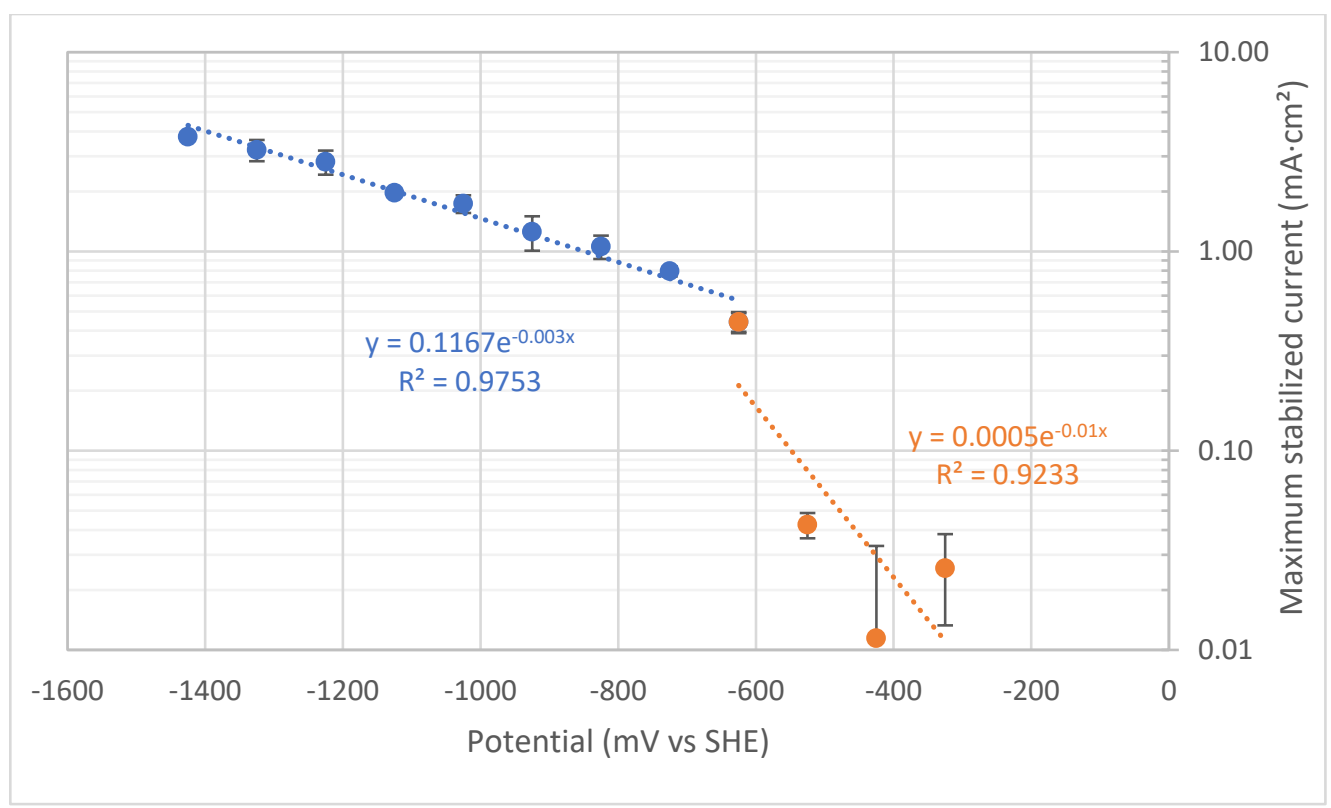

Supplementary figure 3: Exponential regression of the maximum current obtained vs. potential of the cathode. Two separate trends can be observed, here represented by the blue and orange colours. 